ISSN: 2302-8556

E-Jurnal Akuntansi Universitas Udayana

Vol.22.2. Februari (2018): 1557-1583

DOI: https://doi.org/10.24843/EJA.2018.v22.i02.p27

\title{
Pengaruh Profitabilitas pada Nilai Perusahaan dengan Corporate Social Responsibility Sebagai Variabel Intervening
}

\author{
Anak Agung Ayu Tisna Wulan Dewi ${ }^{1}$ \\ Ni Gst. Putu Wirawati ${ }^{2}$
}

${ }^{1}$ Fakultas Ekonomi dan Bisnis Universitas Udayana (Unud), Bali, Indonesia email: dayuwidia96@gmail.com /Telp :081237921765

${ }^{2}$ Fakultas Ekonomi dan Bisnis Universitas Udayana (Unud), Bali, Indonesia

\begin{abstract}
ABSTRAK
Penelitian ini bertujuan untuk mendapatkan bukti empiris mengenai pengaruh profitabilitas padanilai perusahaan dengan corporate social responsibility(CSR) sebagai variabel intervening. Penelitian ini dilakukan pada perusahaan pertambangan yang terdaftar di Bursa Efek Indonesia tahun 2014-2016. Metode penentuan sampel yang digunakan adalah menggunakan teknik purposive sampling. Jumlah perusahaan yang memenuhi kriteria adalah 14 perusahaan dengan jumlah 42 amatan. Pengumpulan data dilakukan dengan metode observasi non partisipan. Teknik Analisis data yang digunakan yaitu uji Path Analysis (Analisis Jalur). Hasil dari pengujian pada penelitian ini menunjukkan variabel profitabilitas berpengaruh positif pada nilai perusahaan. Sedangkan variabel CSR tidak berpengaruh pada nilai perusahaan. Variabel profitabilitas berpengaruh positif pada pengungkapan CSR. Pada penelitian ini tidak ditemukannya peran CSR memediasi pengaruh profitabilitas pada nilai perusahaan.
\end{abstract}

Kata Kunci: Profitabilitas, corporate social responsibility, nilai perusahaan

\section{ABSTRACT}

This study aims to obtain empirical evidence on the influence of profitability on corporate value with corporate social responsibility (CSR) as intervening variable. This research is conducted on mining companies listed on Indonesia Stock Exchange 20142016. Sample determination method used is to use purposive sampling technique. The number of companies that meet the criteria is 14 companies with the number of 42 observations. Data collection was done by non participant observation method. Technique Analysis of data used is Path Analysis (Path Analysis). The result of testing in this study shows that profitability variables have a positive effect on firm value. While the CSR variable has no effect on firm value. Profitability variables have a positive effect on CSR disclosure. In this research, CSR's role is not found to mediate the effect of profitability on firm value.

Keywords: Profitability, corporate social responsibility, corporate value

\section{PENDAHULUAN}

Perusahaan merupakan suatu organisasi yang terdiri atas sekelompokorang yang bekerja untuk rnencapai suatu tujuan. Kepentingan yang paling mendasar yaitu mendapatkan keuntungan atau laba semaksimal mungkin serta kesejahteraan bagi para pemegang saham perusahaan. Peningkatan nilai perusahaan yang tinggi merupakan tujuan jangka panjang yang seharusnya dicapaiperusahaan (Anggraini, 
A.A.Ayu Tisna Wulan Dewi dan Ni Gst. Putu Wirawati. Pengaruh...

2013). Nilai perusahaan yang tinggi dapat meningkatkan kemakmuran bagi para pemegang saham, sehingga para pemegang saham akanmenginvestasikan modalnya kepada perusahaan tersebut (Haruman, 2008).

Nilai perusahaan lazim diindikasikan dengan price to book value (PBV). PBVtinggi akan membuat pasar percaya atas prospek perusahaan kedepan. Hal itu juga yang menjadi keinginan para pemilik perusahaan, sebab nilai perusahaan yang tinggi mengindikasikan kemakmuran pemegang saham juga tinggi (Soliha dan Taswan, 2002). Namun berdasarkan data yang tersedia di Bursa Efek Indonesia membuktikan adanya tren penurunan nilai perusahaan yang akan mempengengaruhi kepercayaan para calon investor untuk menanamkan modal pada perusahaan.

. Nilai perusahaan dapat dicapai dengan maksimum jika para pemegang saham menyerahkan urusan pengelolaan perusahaan kepada orang-orang yang berkompeten dalam bidangnya, seperti manajer maupun komisaris. Namun, dalam meningkatkan nilai perusahaan akan muncul masalah kepentingan antara agen (manajer) dan prinsipal (pemegang saham). Tidak jarang manajer perusahaan mempunyai tujuan dan kepentingan lain yang bertentangan dengan tujuan utama perusahaan dan sering mengabaikan kepentingan pemegang saham. Perbedaan kepentingan antara manajer dan pemegang saham ini mengakibatkan timbulnya konflik yang biasa disebut agensi konflik, hal tersebut terjadi karena manajer lebih mengutamakan kepentingan pribadinya sebaliknya pemegang saham tidak menyukai kepentingan pribadi dari manajer karena apa yang dilakukan manajer tersebut akan menambah biaya bagi perusahaan sehingga menyebabkan 
penurunan keuntungan perusahaan dan berpengaruh terhadap harga saham sehingga menurunkan nilai perusahaan (Jensen dan Meckling, 1976).

Salah satu faktor yang memengaruhi nilai perusahaan merupakan profitabilitas. Menurut Dewi (2013) nilai perusahaan dapat pula dipengaruhi oleh besar kecilnya profitabilitas yang dihasilkan oleh perusahaan. Profitabilitas adalah kemampuan suatu perusahaan untuk menghasilkan laba selama periode tertentu. Menurut Agustina (2012) para investor menanamkan saham pada perusahaan adalah untuk mendapatkan return yang terdiri dari yield dan capital gain.Menurut Maria (2013) laba merupakan elemen dalam menciptakan nilai perusahaan karena penilaian prestasi perusahaan dilihat dari kemampuan perusahaan tersebut dalam menghasilkan laba. Return on Asset (ROA) adalah rasio yang mengukur kemampuan dari modal yang diinvestasikan dalam keseluruhan aktiva untuk menghasilkan neto. Nilai ROA yang tinggi merupakan sinyal positif bagi investor untuk memprediksi bahwa perusahaan dikemudian hari dalam kondisi yang menguntungkan. Hal ini selanjutnya akan meningkatkan daya tarik perusahaan kepada investor. Jadi dalam penelitian ini tingkat profitabilitas digunakan untuk mengukur kinerja keuangan perusahaan. Hal ini sejalan dengan penelitian yang dilakukan Yuniasih dan Wirakusuma (2009), Syarifa (2013) dan Dinata (2013) menemukan bahwa ROA berpengaruh positif terhadap nilai perusahaan. Sedangkan menurut Astriari (2014) menunjukkan bahwa tidak adanya pengaruh antara profitabilitas yang di proksikan dengan ROA terhadap CSR dan nilai perusahaan begitu pula hasil dari Wibowo (2011) menemukan profitabilitas yang 
A.A.Ayu Tisna Wulan Dewi dan Ni Gst. Putu Wirawati. Pengaruh...

diproksikan melalui return on asset (ROA) tidak berpengaruh terhadap nilai perusahaan.

Berdasarkan hasil yang belum konsisten yang ditemukan pada penelitianpenelitian sebelumnya tentang profitabilitas terhadap nilai perusahaan serta mengingat masih pentingnya mengetahui faktor-faktor yang memengaruhi nilai perusahaan, maka peneliti memutuskan untuk meneliti kembali demi mendapatkan hasil penelitian yang lebih akurat dengan menambahkan satu variabel interveningke dalam penelitian ini, yaitu Corporate Social Responsibility (CSR). Variabel CSRdigunakan sebagai variabel intervening karena variabel ini berperan dalam memberikan pengaruh profitabilitas terhadap nilai perusahaan secara tidak langsung. Hal ini dapat dijelaskan dalam teori sinyal yang menjelaskan bahwa dengan kinerja perusahaan yang baik cendrung mengungkapkan informasi CSR secara lengkap kepada publik, dengan tujuan membangun image perusahaan yang positif. Seiring dengan hal tersebut, para investor akan tertarik untuk berinvestasi sehingga akan berdampak pada peningkatan nilai perusahaan yang dicerminkan melalui harga saham perusahaan tersebut.

Tanggung jawab sosial perusahaan atau CSRmerupakan faktor lain yang sekarang ini perlu dipertimbangkan oleh perusahaan dalam upaya meningkatkan nilai perusahaan. CSR sering dianggap inti dari etika bisnis, yang berarti bahwa perusahaan tidak hanya mempunyai kewajiban-kewajiban ekonomi dan legal tetapi juga kewajiban-kewajiban terhadap pihak-pihak lain yang berkepentingan (stakeholder) yang jangkauannya melebihi kewajiban kewajiban ekonomi dan 
legal (Kusumadilaga, 2010). Pengelolaan yang dulunya shareholders-focused ke steakholders-focused menyebabkan perusahaan mengadopsi konsep triple bottom line.

Konsep triple bottom line merupakan konsep pengukuran kinerja perusahaan dengan memasukkan tak hanya ukuran kinerja ekonomis berupa perolehan profit, tapi juga ukuran kepedulian sosial dan pelestarian lingkungan. Konsep ini memasukkan tiga ukuran kinerja sekaligus yaitu ekonomi, lingkungan, dan sosial. Konsep triple bottom line mengimplikasikan bahwa perusahaan harus lebih mengutamakan kepentingan steakholders dari pada kepentingan shareholders (Pebriana dan Sukartha, 2012).

Perusahaan pertambangan dipilih sebagai objek penelitian dikarenakan perusahaan pertambanganmerupakan perusahaan yang kegiatan operasinya berkaitan erat dengan eksploitasi sumber daya alam serta memiliki dampak terkaitan kerusakan lingkungan sekitar wilayah lingkungan pertambangan. Selain itu sektor pertambangan juga sektor yang memiliki nilai kapitasilasi yang besar di bandingkan sektor lain sehingga membuat sektor pertambangan ini merupakan sektor yang kuat dan sangat diminati oleh investor. Penelitian ini menggunakan periode waktu dari tahun 2014-2016. Alasan memilih periode waktu dari tahun 2014-2016 karena belum diteliti pada penelitian-penelitian sebelumnya dan kriteria sampel yang diteliti pada penelitian ini berbeda dengan penelitianpenelitian sebelumnya. Oleh karena itu, penelitian ini dilakukan untuk mengetahui apakah hasil yang akan diperoleh nantinya dapat mendekati hasil atau berbeda hasil dengan penelitian-penelitian sebelumnya. 
A.A.Ayu Tisna Wulan Dewi dan Ni Gst. Putu Wirawati. Pengaruh...

Adapun rumusan masalah dalam penelitian ini adalah 1) Apakah profitabilitas berpengaruh pada nilai perusahaan? 2) Apakah profitabilitas berpengaruh pada CSR? 3) Apakah CSR berpengaruh pada nilai perusahaan? 4) Apakah CSR dapat memediasi pengaruh profitabilitas pada nilai perusahaan?

Teori sinyal menjelaskan alasan perusahaan untuk memberikan informasi terkait aktivitas bisnisnya kepada pihak eksternal, seperti investor, kreditur dan masyarakat. Dorongan ini dikarenakan adanya asimetris informasi antara perusahaan dan pihak eksternal, karena perusahaan mengetahui lebih banyak mengenai kegiatan dan prospek perusahaan di masa yang akan datang dibandingkan pihak eksternal. Perusahaan pun harus mengungkapkan informasi yang dimilikinya, dimana salah satunya adalah laporan mengenai CSR, untuk mengurangi adanya asimetris informasi tersebut (Rustariani, 2010).

Sinyal secara umum dapat diartikan sebagai suatu isyarat yang ditunjukkan oleh perusahaan (manajer) kepada pihak luar. Sinyal ini dapat berupa promosi atau informasi lain yang menunjukkan bahwa perusahaan tersebut lebih baik dibandingkan perusahaan lainnya. Apapun bentuk maupun jenis sinyal yang dikeluarkan oleh perusahaan, semuanya bertujuan agar pihak eksternal dapat melakukan perubahan penilaian atas perusahaan atau dengan kata lain perusahaan harus mengeluarkan sinyal yang memiliki kekuatan informasi yang mampu mengubah penilaian pihak eksternal perusahaan (Gumanti, 2009:4).

Kesejahteraan pemilik perusahaan dicerminkan melalui peningkatan nilai perusahaan, hal ini menyebabkan pemilik perusahaan akan mendorong manajer agar bekerja keras guna meningkatkan nilai perusahaan (Pradipta, 2010). Secara 
normatif tujuan manajer dalam keputusan keuangan adalah untuk memaksimumkan nilai perusahaan atau memaksimumkan kemakmuran pemegang saham. Nilai perusahaan merupakan persepsi investor terhadap perusahaan, yang sering dikaitkan dengan harga saham. Harga saham yang tinggi membuat nilai perusahaan juga tinggi. Nilai perusahaan lazim diindikasikan dengan price to book value(PBV). PBV yang tinggi akan membuat pasar percaya atas prospek perusahaan kedepan. Hal itu juga yang menjadi keinginan para pemilik perusahaan, sebab nilai perusahaan yang tinggi mengindikasikan kemakmuran pemegang saham juga tinggi (Soliha dan Taswan, 2002). Semakin tinggi nilai perusahaan, semakin besar kemakmuran yang akan diterima oleh pemilik perusahaan (Wiagustini, 2010:8).

Nilai perusahaan sangat penting karena menunjukkan seberapa besar perusahaan tersebut dapat memberikan keuntungan bagi investor. Nilai perusahaan pada dasarnya diukur dari beberapa aspek salah satunya adalah harga pasar saham perusahaan, karena harga pasar saham perusahaan mencerminkan penilaian investor atas keseluruhan ekuitas yang dimiliki (Wahyudi dan Pawestri, 2006).

Nilai perusahaan dapat dilihat dari PBV yang merupakan perbandingan antara harga saham dengan nilai buku per lembar saham. PBVmerupakan rasio antara harga perlembar saham dengan nilai buku perlembar saham. Nilai buku dapat dicari dengan cara modal dibagi dengan jumlah saham yang beredar. Nilai buku per lembar saham menunjukkan jumlah rupiah yang akan dibayarkan kepada setiap lembar saham apabila perusahaan pada saat itu dibubarkan dengan 
A.A.Ayu Tisna Wulan Dewi dan Ni Gst. Putu Wirawati. Pengaruh...

anggapan bahwa semua aktiva dapat direalisir atau dijual dengan harga yang sama dengan nilai bukunya atau menunjukkan jumlah rupiah aktiva perusahaan yang menjadi hak setiap lembar saham (Munawir, 2010).

Menurut The World Business Council for Sustainable Development (WBCSD), Corporate Sosial Responsibility atau tanggung jawab sosial perusahaan didefenisikan sebagai komitmen bisnis untuk memberikan kontribusi bagi pembangunan ekonomi berkelanjutan, melalui kerja sama dengan para karyawan serta perwakilan mereka, keluarga mereka, komonitas setempat maupun masyarakat umum untuk meningkatkan kualitas kehidupan dengan cara bermanfaat baik bagi bisnis sendiri maupun untuk pembangunan (Kusumadilaga, 2010). CSR adalah mekanisme bagi suatu organisasi untuk secara sukarela mengintegrasikan perhatian terhadap lingkungan dan sosial kedalam operasinya dan interaksinya dengan stakeholders, yang melebihi tanggung jawab organisasi dibilang hukum (Darwin, 2007). Mc Wiliams dan Siegel (2001) juga mendifinisikan CSR sebagai aksi yang muncul sebagai lanjutan dari tindakan sosial, melebihi kepentingan perusahaan dan yang di wajibkan oleh hukum.

CSR merupakan suatu pengembangan konsep yang dikemukan oleh John Elkington pada tahun 1997, yaitu “The Triple Botton Line”. Konsep tersebut menyatakan bahwa agar perusahaan dapat mempertahankan keberlangsungannya maka perlu memperhatikan 3P, yaitu tidak hanya profit, namun juga mampu memberikan kontribusi kepada masyarakat (people) serta ikut aktif dalam menjaga kelestarian lingkungan (planet). Konsep CSRmelibatkan tanggung jawab kemitraan antara pemerintah, lembaga sumber daya masyarakat, serta komunitas 
setempat (lokal). Kemitraan ini tidaklah bersifat pasif dan statis. Kemitraan ini merupakan tanggung jawab bersama secara sosial antara stakeholders (Nurlela dan Islahuddin, 2008).

Profitabilitas adalah kemampuan perusahaan untuk menghasilkan keuntungan dan mengukur tingkat efisiensi operasional dan eflsiensi dalam menggunakan harta yang dimilikinya (Ju Chen dan Yu Chen, 2011). Selanjutnya menurut MenurutBrigham (2001), profitabilitas adalah hasil akhir dari serangkaian kebijakan dan keputusan manajemen, dimana kebijakan dan keputusan ini menyangkut pada sumber dan penggunaan dana dalam menjalankan operasional perusahaan yang terangkum dalam laporan neraca dan unsur dalam neraca. Profitabilitas merupakan gambaran dari penilaian kinerja keuangan, ukuran protitabilitas perusahaan dapat berbagaimacam seperti: laba operasi, laba bersih, tingkat pengembalian investasi dan tingkat pengembalian ekuitas pemilik.

Profitabilitas dalam penelitian ini diproksikan melalui ROA sebagai ukuran profitabilitas perusahaan karena ROA merupakan rasio yang paling baik dalam memprediksikan penumbuhan laba. Tangkisilah dalam Nikolis (2013) juga mengemukakan bahwa ROA merupakan ukuran protitabilitas yang lebih baik dari rasio profitabilitas lainnya karena rasio ini dapat mengukur efesiensi operasi. ROA sendiri mempakan perhitungan rasio yang membandingkan tingkat laba bersih setelah pajak dengan total seluruh aktiva yang dimiliki oleh perusahaan. Menurut Adri (2014) ROA mengukur efektivitas tingkat pengembalian yang diperoleh total aktiva di perusahaan. ROA membandingkan besarnya laba bersih terhadap ekuitas saham biasa. 
A.A.Ayu Tisna Wulan Dewi dan Ni Gst. Putu Wirawati. Pengaruh...

Teori sinyal menjelaskan bagaimana perusahaan mengeluarkan sinyal berupa informasi yang dapat menjelaskan keadaan perusahaan tersebut lebih baik dibandingkan dengan perusahaan lainnya. Sinyal yang dikeluarkan perusahaan membantu investor dalam menilai suatu perusahaan. Salah satu informasi yang dikeluarkan perusahaan berupa informasi keuangan yang menjelaskan kinerja keuangan perusahaan tersebut yang diukur dengan menghitung berbagai rasio keuangan. Dalam penelitian ini profitabilitas diproksikan melalui Return on Assets (ROA). ROAmerupakan rasio yang paling baik dalam memprediksikan penumbuhan laba. Menurut Susianti (2013) nilai ROA yang tinggi merupakan sinyal positif bagi investor bahwa perusahaan dalam kondisi yang menguntungkan. Hal ini menjadi daya tarik investor untuk memiliki saham perusahaan dan akan meningkatkan harga saham sehingga nilai perusahaan pun meningkat. Selain itu, peneliti juga berasumsi bahwa profitabilitas menunjukkan tingkat keuntungan bersih yang mampu diraih oleh perusahaan saat menjalankan operasinya. Dengan profitabilitas yang tinggi yang dimiliki sebuah perusahaan akan menarik minat investor untuk menanamkan modalnya diperusahaan maka hal itu dapat meningkatkan nilai perusahaan.

Penelitian mengenai profitabilitas terhadap nilai perusahaan dilakukan oleh Ju Chen dan Yu Chen (2011). Penelitian tersebut menunjukkan bahwa profitabilitas berpengaruh terhadap nilai perusahaan. Penelitian yang dilakukan oleh Su'aidah (2010), Irma (2014) dan Wahyudi (2012) memperkuat penelitian Ju Chen dan Yu Chen (2011) dengan menyatakan bahwa profitabilitas yang 
diproksikan dengan ROA berpengaruh terhadap nilai perusahaan sehingga ketika laba perusahaan naik maka nilai perusahaan akan ikut naik.

Tingginya tingkat profitabilitas perusahaan disebabkan adanya prestasi kinerja yang baik sehingga akan berdampak pada semakin besarnya sumber daya perusahaan dimana perusahaan akan mendapatkan banyak sorotan publik. Perusahaan akan melakukan pengungkapan CSR secara lebih luas agar keberadaan perusahaan dapat diterima oleh stakeholder guna menjamin kelangsungan hidup perusahaan dan mendapatkan laba yang lebih besar di kemudian hari. Penelitian yang dilakukan Sembiring (2005) tidak berhasil membuktikan bahwa profitabilitas berpengaruh negatif pada CSR. Penelitian yang dilakukan oleh Uadiale dan Fagbemi (2012), Vintila dan Duca (2013) serta Sari (2012) juga menunjukkan bahwa profitabilitas berpengaruh positif pada CSR.

Rustiarini (2010) menyatakan bahwa perusahaan akan mengungkapkan suatu informasi jika informasi tersebut dapat meningkatkan nilai perusahaan. Hal ini sesuaidengan teori sinyal, dimana perusahaan akan memberikan sinyal kepada pihak luar, baik itu investor maupun masyarakat berupa informasi yang menunujukkan bahwa perusahaan tersebut memiliki kinerja yang lebih baik dibandingkan perusahaan lain.Sinyal positif ini pun diharapkan dapat membantu perusahaan dalam membangun image perusahaan yang positif, sehingga berdampak pada kinerja pasar perusahaan yang tercermin dalam harga pasar saham perusahaan, yang berarti juga meningkatkan nilai perusahaan (Kusumadilaga, 2010). Peneliti berasumsi bahwa CSR dalam hal ini diharapkan dapat memberikan sinyal positif kepada para stakeholder-nya, karena laporan ini 
A.A.Ayu Tisna Wulan Dewi dan Ni Gst. Putu Wirawati. Pengaruh...

akan menunjukkan bahwa perusahaan jugamemiliki kepedulian dan rasa tanggung jawab kepada lingkungan dan stakeholder-nya sehingga image perusahaan menjadi positif dan pada akhirnya dapat meningkatkan nilai perusahaan.Penelitian yang mengaitkan CSR dengan nilai perusahaan diungkapkan oleh Nguyen et al. (2015), Fodio et al. (2013, Gherghina et al. (2014), Murwaningsari (2009), Rustiarini (2010) serta Harjoto dan Jo (2011) yang mendukung hipotesis yang menyatakan bahwa tingkat pengungkapan informasi CSR dalam laporan tahunan perusahaan berpengaruh positif pada nilai perusahaan.

Teori sinyal menyatakan bahwa pihak eksekutif perusahaan memiliki informasi lebih baik mengenai perusahaannya akan terdorong untuk menyampaikan informasi tersebut kepada calon investor agar harga saham perusahaannya meningkat (Ross, 1977). Apabila profitabilitas meningkat, maka perusahaan semakin aktif dalam mengungkapkan tanggung jawab sosial dan lingkungannya (Rani, 2013). Tingginya tingkat profitabilitas perusahaan disebabkan adanya prestasi kinerja yang baik sehingga akan berdampak pada semakin besarnya sumber daya perusahaan dimana perusahaan akan mendapatkan banyak sorotan publik. Perusahaan akan melakukan pengungkapan CSR secara lebih luas agar keberadaan perusahaan dapat diterima oleh stakeholder guna menjamin kelangsungan hidup perusahaan dan mendapatkan laba yang lebih besar di kemudian hari.Penelitian yang dilakukan Sembiring (2005) tidak berhasil membuktikan bahwa profitabilitas berpengaruh negatif pada CSR. Penelitian yang dilakukan oleh Uadiale dan Fagbemi (2012), Vintila dan Duca (2013) serta Sari (2012) juga menunjukkan bahwa profitabilitas berpengaruh positif pada CSR. 
Nilai perusahaan dipengaruhi oleh beberapa faktor, dua diantaranya yaitu profitabilitas dan CSR. Semakin tinggi profitabilitas, maka semakin tinggi pula kedudukan nilai perusahaan di mata investor. Teori sinyal menekankan bahwa perusahaan dapat mengirimkan sinyal kepada pihak eksternal melalui pelaporan informasi terkait kinerja perusahaan untuk meminimalisir ketidakpastian akan prospek perusahaan di masa mendatang dengan tujuan meningkatkan nilai perusahaan (Putra dkk, 2013). Semakin tinggi profitabilitas, maka semakin tinggi pula kedudukan nilai perusahaan di mata investor. Pelaporan informasi terkait peningkatan profitabilitas dan pengungkapan CSR yang lebih luas akan memberikan dampak pada kualitas laporan keuangan perusahaan, dimana laporan tersebut sebagai bahan pertimbangan dalam mengambil keputusan berinvestasi bagi investor. Kedua informasi tersebut dapat menggambarkan prospek bisnis yang baik di masa depan sehingga akan ditangkap oleh investor sebagai sinyal positif dimana berdampak pada meningkatnya harga saham dan nilai perusahaan.

Berdasarkan paparan teori serta penelitian terdahulu dapat disusun hipotesis sebagai jawaban sementara pada penelitian ini sebagai berikut:

$\mathrm{H}_{1}$ : Profitabilitas berpengaruh positif pada nilai perusahaan

$\mathrm{H}_{2}$ : Profitabilitas berpengaruh positif pada CSR

$\mathrm{H}_{3}$ : CSR berpengaruh positif pada Nilai Perusahaan

$\mathrm{H}_{4}$ : Peran CSR memediasi pengaruh Profitabilitas pada Nilai Perusahaan

\section{METODE PENELITIAN}

Jenis data yang dikumpulkan dalam penelitian ini adalah data kuantitatif. Data kuantitatif merupakan data yang dapat dinyatakan dalam bentuk angka-angka 
A.A.Ayu Tisna Wulan Dewi dan Ni Gst. Putu Wirawati. Pengaruh...

(Sugiyono, 2014: 12). Data yang digunakan dalam penelitian ini adalah laporan keuangan tahunan perusahaan pertambangan selama periode 2014-2016 yang diunduh di website Bursa Efek Indonesia (www.idx.co.id). Sumber data yang digunakan dalam penelitian ini adalah Data sekunder yang dapat diperoleh dari laporan keuangan pada perusahaan pertambangan yang terdaftar di Bursa Efek Indonesia tahun 2014-2016 yang dapat di unduh melalui website(www.idx.co.id). Dalam penelitian ini terdapat tiga variabel yang diteliti, yaitu variabel independent (bebas), variabel dependent (terikat), dan variabel intervening (mediasi). Variabel bebas adalah variabel yang memengaruhi atau yang menjadi sebab perubahan atau timbulnya variabel terikat (Sugiyono, 2014).Variabel bebas penelitian ini adalah Profitabilitas (X).

Variabel terikat adalah variabel yang dipengaruhi atau disebut juga variabel yang menjadi akibat, karena adanya variabel bebas (Sugiyono, 2014) Variabel terikat dalam penelitian ini adalah nilai perusahaan (Y). Variabel intervening adalah variabel penyela atau antara yang terletak diantara variabel bebas dan variabel terikat sehingga variabel bebas tidak langsung memengaruhi berubahnya atau timbulnya variabel terikat (Sugiyono, 2014). Variabel mediasi dalam penelitian ini adalah CSR (M). Populasi merupakan wilayah generalisasi yang terdiri atas objek dan subjek yang mempunyai kualitas tertentu yang ditetapkan untuk dipelajari oleh peneliti (Sugiyono, 2014: 115). Populasi pada penelitian ini adalah seluruh perusahaanpertambanganyang terdaftar di Bursa Efek Indonesia tahun 2014-2016. 
Sampel pada penelitian ini diambil dengan menggunakan teknikpurposive sampling berdasarkan teknik penentuan sampel dengan pertimbangan tertentu (Sugioyono, 2014: 122). Pada penelitian ini metode yang digunakan adalah metode observasi nonpartisipan. Metode observasi nonpartisipan yaitu teknik pengumpulan data dengan cara observasi atau pengamatan dimana peneliti tidak terlibat langsung, tetapi hanya sebagai pengamat independen (Sugiyono, 2014: 405). Teknik analisis data yang digunakan dalam penelitian ini, antara lain uji asumsi klasik, analisis jalur (path analysis) dan uji sobel.

\section{HASIL DAN PEMBAHASAN}

Statistik deskriptif memberikan informasi mengenai karakteristik variabelvariabel penelitian yang terdiri atas jumlah pengamatan, nilai minimum, nilai maksimum, nilai mean, dan standar deviasi. Tabel 1. memperlihatkan hasil statistik deskriptif.

\section{Tabel 1.}

Hasil Uji Statistik Deskriptif

\begin{tabular}{lccccc}
\hline & N & Minimum & Maximum & Mean & Std. Deviation \\
\hline ROA & 42 &,- 7213 &, 3200 &, 026340 &, 1438163 \\
CSRDI & 42 &, 1428 &, 3956 &, 264571 &, 0594444 \\
PBV & 42 &, 1700 & 2,9400 & 1,118571 &, 7025965 \\
Valid N (listwise) & 42 & & & & \\
& & & & & \\
\hline
\end{tabular}

Sumber: Data diolah, 2017

Hasil uji statistik deskriptif pada Tabel 1. diatas, didapatkan informasi bahwa variabel ROA (Profitabilitas) memiliki nilai minimum sebesar -0,7213 (MITI) nilai maksimum sebesar 0,3200 (MBAP) mean sebesar 0,26340 dan standar deviasi sebesar 0,1438163. Ini berarti bahwa terjadi perbedaan nilai ROA yang diteliti terhadap nilai rata-ratanya sebesar 0,1438163 . 
A.A.Ayu Tisna Wulan Dewi dan Ni Gst. Putu Wirawati. Pengaruh...

Variabel CSR memiliki nilai minimum sebesar 0,1428 (MITI) nilai maksimum sebesar 0,3956 (ITMG) mean sebesar 0,264571 dan standar deviasi sebesar 0,0594444. Ini berarti bahwa terjadi perbedaan nilai CSRyang diteliti terhadap nilai rata-ratanya sebesar 0,0594444 .

Variabel PBV (Nilai Perusahaan) memiliki nilai minimum sebesar 0,1700 (ARTII) nilai maksimum sebesar 2,9400 (MBAP) mean sebesar 1,118571dan standar deviasi sebesar 0,7025965. Ini berarti bahwa terjadi perbedaan nilai PBVyang diteliti terhadap nilai rata-ratanya sebesar 0,7025965.

Tujuan dari pengujian ini adalah untuk memastikan bahwa model atau persamaan yang diuji tidak melanggar asumsi tersebut. Pengujian ini dilakukan untuk membuktikan bahwa hasil yang diperoleh bersifat BLUE (Best Linear Unbiased Estimator). Pengujian tersebut diantaranya adalah normalitas, multikolinearitas, autokorelasi, dan heteroskedastisitas.

Tabel 2.

Hasil Uji Asumsi Klasik

\begin{tabular}{lll}
\hline Uji Asumsi Klasik & Hasil Uji & Keterangan \\
\hline Uji Normalitas & $\mathrm{p}(0,200)>0,05 ; \mathrm{p}(0,260)$ & Berdistribusi normal \\
Uji Multikolinearitas & Tolerance $(0,893) ;(0,893)<$ & \\
& 0,1 & Tidak ada multikolinearitas \\
& VIF $(1,120) ;(1,120)<10$ & \\
Uji Autokorelasi & $(1,5534<2,092<2,4466) ;$ & Tidak terdapat autokorelasi \\
& $(1,6061<2,105<2,3939)$ & \\
Uji Heterokedastisitas & $\mathrm{p}(0,346)>0,05 ; \mathrm{p}(0,447)>$ & Tidak terjadi \\
& 0,$05 ; \mathrm{p}(0,089)>0,05$ & heteroskedastisitas \\
\hline
\end{tabular}

Sumber: Data Diolah, 2017

Pengujian data dalam penelitian ini menggunakan teknik analisis jalur (Path Analysis), dimana analisis jalur adalah perluasan dari analisis regresi linear berganda untuk menguji hubungan kausalitas antara 2 atau lebih variabel. 
ISSN: 2302-8556

E-Jurnal Akuntansi Universitas Udayana

Vol.22.2. Februari (2018): 1557-1583

Tabel 3.

Hasil Analisis Jalur Struktur 1

\begin{tabular}{|c|c|c|c|c|c|}
\hline \multirow[t]{3}{*}{ Model } & \multicolumn{5}{|c|}{ Standardized } \\
\hline & \multicolumn{2}{|c|}{ Unstandardized Coefficients } & \multirow{2}{*}{$\frac{\text { Coefficients }}{\text { Beta }}$} & \multirow[b]{2}{*}{$\mathbf{T}$} & \multirow[b]{2}{*}{ Sig. } \\
\hline & B & Std. Error & & & \\
\hline (Constant) & 0.216 & 0.09 & & 29.251 & 0.000 \\
\hline ROA & 0.135 & 0.62 & 0.328 & 2.194 & 0.034 \\
\hline R Square & 0,328 & & & & \\
\hline Adjusted $\mathrm{R}^{2}$ & 0,107 & & & & \\
\hline F Hitung & 4,815 & & & & \\
\hline Sig F & 0,034 & & & & \\
\hline
\end{tabular}

Berdasarkan Tabel 3. Dapat dibuat persamaan sebagai berikut:

$$
\mathrm{Y}=0,216+0,328 \mathrm{X}
$$

Berdasarkan persamaan analisis jalur struktur 1 di atas, dapat dijelaskan hal-hal yaitu nilai konstanta sebesar 0,216, jika nilai profitabilitas (X) sama dengan nol, maka nilai perusahaan (Y) tidak meningkat atau sama dengan 0,216satuan. $\beta_{1}=0,328$, jika nilai profitabilitas $(X)$ bertambah 1 satuan, maka nilai dari nilai perusahaan (Y) akan bertambah sebesar 0,328 persen dengan asumsi variabel bebas lainnya konstan. Tabel 3. tersebut diketahui bahwa nilai koefisien regresi $\mathrm{X}$ atau $\mathrm{ROA}$ adalah sebesar 0,328 dengan tingkat signifikansi sebesar 0,034 lebih kecil dibandingkan dengan taraf nyata $\alpha=0,05$. Hal ini menunjukan bahwa variabel profitabilitas berpengaruh positif pada CSR pada perusahaan pertambangan yang terdaftar di Bursa Efek Indonesia Periode 2014-2016, maka hipotesis kedua $\left(\mathrm{H}_{2}\right)$ diterima. Berdasarkan persamaan di atas, dapat dijelaskan hal-hal yaitu nilai konstanta sebesar 1,455 , jika nilai profitabilitas (X) dan CSR (M) sama dengan nol, maka nilai perusahaan (Y) tidak meningkat atau sama dengan $-1,455$ satuan. $\beta_{1}=0,373$, jika nilai profitabilitas $(\mathrm{X})$ bertambah 1 satuan, maka nilai dari nilai perusahaan (Y) akan bertambah sebesar 0,373 persen dengan asumsi variabel bebas lainnya konstan. $\beta_{2}=0,123$, jika nilai CSR (M) bertambah 1 
satuan, maka nilai dari nilai perusahaan (Y) akan bertambah sebesar 0,123 persen dengan asumsi variabel bebas lainnya konstan.

Tabel 4.

Hasil Analisis Jalur Struktur 2

\begin{tabular}{|c|c|c|c|c|c|c|c|}
\hline \multirow{2}{*}{\multicolumn{2}{|c|}{ Model }} & \multicolumn{3}{|c|}{ Unstandardized Coefficients } & \multirow{2}{*}{$\begin{array}{c}\begin{array}{c}\text { Standardized } \\
\text { Coefficients }\end{array} \\
\text { Beta } \\
\end{array}$} & \multirow[b]{2}{*}{$\mathbf{T}$} & \multirow[b]{2}{*}{ Sig. } \\
\hline & & B & & Std. Error & & & \\
\hline \multirow[t]{3}{*}{1} & (Constant) & & 1.455 & 0.501 & & 2.907 & 0.006 \\
\hline & ROA & & 1.822 & 0.775 & 0.373 & 2.351 & 0.024 \\
\hline & CSR & & -1.455 & 1.875 & -0.123 & -0.776 & 0.443 \\
\hline \multicolumn{2}{|c|}{ R Square } & 0,124 & & & & & \\
\hline \multicolumn{2}{|c|}{ Adjusted $\mathrm{R}^{2}$} & 0,079 & & & & & \\
\hline \multicolumn{2}{|c|}{ F Hitung } & 2,765 & & & & & \\
\hline \multicolumn{2}{|c|}{ Sig F } & 0,075 & & & & & \\
\hline
\end{tabular}

Sumber: Data diolah, 2017

Berdasarkan Tabel 4. tersebut dapat dibuat persamaan sebagai berikut:

$$
\mathrm{Y}=1,455+0,373 \mathrm{X}-0,123 \mathrm{M}
$$

Berdasarkan Tabel 4. tersebut diketahui bahwa nilai koefisien regresi Xatau ROA adalah sebesar 0,373 dengan tingkat signifikansi sebesar 0,024 lebih kecil dibandingkan dengan taraf nyata $\alpha=0,05$. Hal ini menunjukan bahwa variabel profitabilitas berpengaruh positif pada nilai perusahaan pada perusahaan pertambangan yang terdaftar di Bursa Efek Indonesia Periode 2014-2016, maka hipotesis pertama $\left(\mathrm{H}_{1}\right)$ diterima.

Dari Tabel 4. tersebut diketahui bahwa nilai koefisien regresi M atau CSR adalah sebesar -0,123 dengan tingkat signifikansi sebesar 0,443 lebih besar dibandingkan dengan taraf nyata $\alpha=0,05$. Hal ini menunjukan bahwa variabel CSR tidak berpengaruh pada nilai perusahaan pada perusahaan pertambangan yang terdaftar di Bursa Efek Indonesia Periode 2014-2016, maka hipotesis pertama $\left(\mathrm{H}_{3}\right)$ ditolak. 
Sedangkan koefisien determinasi total dihitung dengan rumus sebagai berikut:

$$
\begin{aligned}
\mathrm{R}_{\mathrm{m}}^{2} & =1-\left(\mathrm{e}_{1}\right)^{2}\left(\mathrm{e}_{2}\right)^{2} \ldots \ldots \ldots \ldots \ldots \\
& =1-(0,819)^{2}(0,935)^{2} \\
& =1-(0,670)(0,874) \\
& =1-0,585=0,415
\end{aligned}
$$

Nilai determinasi total sebesar 0,415 mempunyai arti bahwa sebesar 41,5\% variasi Nilai Perusahaan(Y)dipengaruhi oleh variasi Profitabilitas $(\mathrm{X})$, dan CSR (M), sedangkan sisanya sebesar 58.5\% dijelaskan oleh faktor lain yang tidak dimasukkan ke dalam model.

Berikut perhitung besarnya pengaruh langsung dan pengaruh tidak langsung serta pengaruh total antar variabel. Perhitungan pengaruh antar variabel dirangkum dalam Tabel 5. sebagai berikut.

Tabel 5.

Pengaruh Langsung dan Pengaruh Tidak Langsung

\begin{tabular}{cccc}
\hline $\begin{array}{c}\text { Pengaruh } \\
\text { Variabel }\end{array}$ & $\begin{array}{c}\text { Pengaruh } \\
\text { Langsung }\end{array}$ & Pengaruh Tidak Langsung Melalui CSR & Pengaruh Total \\
\hline $\mathrm{X} \rightarrow \mathrm{M}$ & 0,328 & - & 0,328 \\
$\mathrm{M} \rightarrow \mathrm{Y}$ & $-0,123$ & - & $-0,123$ \\
$\mathrm{X} \rightarrow \mathrm{Y}$ & 0,373 & -0.040 & 0,333 \\
\hline \multicolumn{2}{l}{ Sumber: Data diolah, 2017} &
\end{tabular}

Berdasarkan hasil uji analisis jalur yang telah dirangkum dalam Tabel 5. pada penelitian ini, diperoleh nilai Pengaruh Tidak Langsung (PTL) variabel yaitu Profitabilitas (X) sebesar -0.040. Hal ini menunjukkan bahwa nilai pengaruh langsung variabel lebih besar dari pengaruh tidak langsung, sehingga dapat 
A.A.Ayu Tisna Wulan Dewi dan Ni Gst. Putu Wirawati. Pengaruh...

disimpulkan bahwa CSR bukan merupakan variabel intervening atau mediasi antara variabel Profitabilitas (X) pada Nilai Perusahaan (Y).

Uji sobel digunakan untuk menguji kekuatan pengaruh tidak langsung variabel profitabilitas (X) pada nilai perusahaan (Y) melalui variabel CSR (M)). Uji sobel merupakan alat analisis untuk menguji signifikansi dari hubungan tidak langsung antara variabel independen dengan variabel dependen yang dimediasi oleh variabel mediator. Uji Sobel dirumuskan dengan persamaan berikut dan dapat dihitung dengan menggunakan aplikasi Microsoft Excel 2007. Bila nilai kalkulasi Z lebih besar dari 1,96 (dengan tingkat kepercayaan 95 persen), maka variabel mediator dinilai secara signifikan memediasi hubungan antara variabel terikat dan variabel bebas. Besarnya nilai $\mathrm{Z}$ dapat dihitung dengan rumus sebagai berikut:

$$
Z=\frac{t}{S a b}=a b \sqrt{b^{2} s_{a}^{2}+a^{2} s_{b}^{2}+s_{a}^{2} s_{b}^{2}}
$$

\section{Keterangan:}

$\mathrm{S}_{\mathrm{a}} \quad$ : standar error koefisien a

$\mathrm{S}_{\mathrm{b}} \quad$ : standar error koefisien $\mathrm{b}$

a $\quad$ koefisien path $\mathrm{X}$ terhadap $\mathrm{M}$

b : koefisien path $\mathrm{M}$ terhadap $\mathrm{Y}$

$\mathrm{ab} \quad$ : hasil kali koefisien path $\mathrm{X}$ terhadap koefisien path $\mathrm{M}$ (a) dengan path $\mathrm{M}$ terhadap Y (b)

Perhitungan uji Sobel variabel X- M - Y adalah sebagai berikut:

$$
Z=(0,328) x(-0,123) \sqrt{\left(-0,123^{2}\right) 0,620^{2}+0,328^{2} 1,875^{2}+1,875^{2} 0,620^{2}}
$$

$$
=\frac{-0,040344}{\sqrt{1,73543454}}=-0,03062491
$$


Berdasarkan hasil Uji Sobel variabel Profitabilitas pada Nilai Perusahaan melalui variabel CSR (X-M-Y) menunjukkan bahwa hasil tabulasi $\mathrm{Z}=$ $0,03062491<1,96$ dengan tingkat signifikansi $0,975>0,05$ yang berarti variabel mediator yakni CSR dinilai tidak memediasi hubungan antara profitabilitas pada nilai perusahaan.

Penelitian ini menghasilkan simpulan mengenai bagaimana pengaruh Profitabilitas pada Nilai Perusahaan dengan CSR sebagai variabel intervening. Penelitian ini teori sinyal menjelaskan alasan perusahaan untuk memberikan informasi terkait aktivitas bisnisnya kepada pihak eksternal, seperti investor, kreditur dan masyarakat. Dengan demikian sinyal yang dikeluarkan perusahaan membantu investor dalam menilai suatu perusahaan. Salah satu informasi yang dikeluarkan perusahaan berupa informasi keuangan yang menjelaskan kinerja keuangan perusahaan tersebut yang diukur dengan menghitung berbagai rasio keuangan. Dengan profitabilitas yang tinggi yang dimiliki sebuah perusahaan akan menarik minat investor untuk menanamkan modalnya diperusahaan maka hal itu dapat meningkatkan nilai perusahaan. Hal ini ditunjukan dengan koefisien regresi yang bernilai positif. Penelitian ini juga membuktikan tidak semua variabel yang secara teori memengaruhi nilai perusahaan ketika dilakukan penelitian berpengaruh secara nyata, hal ini dimungkinkan terjadi karena adanya perbedaan objek penelitian, periode penelitian, dan kondisi yang berbeda.

Penelitian ini diharapkan akan memberikan kontribusi positif bagi semua pihak khususnya pihak investor dan perusahaan. Bagi pihak perusahaan hendaknya bersungguh-sungguh dalam penerapan pengungkapan CSR karena 
program tersebut dapat membuat image perusahaan menjadi baik dipandangan investor serta dapat menjadi bahan pertimbangan bagi perusahaan dalam membuat kebijkan. Bagi pihak investor dalam berinvestasi tetap memperhatikan rasio profitabilitas dan penerapan CSRdari perusahaan dan bagi investor yang akan berinvestasi juga mempertimbangkan masing - masing aspek yaitu Profitabilitas dan CSR, hal ini penting karena aspek tersebut dapat mempengaruhi keputusan investor dalam berinvestasi.

\section{SIMPULAN}

Berdasarkan pada hasil analisis data dan pembahasan yang telah dipaparkan maka dapat ditarik kesimpulan bahwa profitabilitas berpengaruh positif pada nilai perusahaan pada perusahaan Pertambangan yang terdaftar di Bursa Efek Indonesia Periode 2014-2016. Profitabilitas yang tinggi yang dimiliki sebuah perusahaan akan menarik minat investor untuk menanamkan modalnya diperusahaan sehingga dapat meningkatkan nilai perusahaan. Profitabilitas berpengaruh positif pada CSR pada perusahaan Pertambangan yang terdaftar di Bursa Efek Indonesia Periode 2014-2016. Perusahaan dengan tingkat profitabilitas yang tinggi akan menjadi sorotan publik, sehingga perusahaan tersebut harus lebih banyak mengungkapkan informasi mengenai pertanggungjawaban sosialnya.

CSR tidak berpengaruh pada nilai perusahaan pada perusahaan Pertambangan yang terdaftar di Bursa Efek Indonesia Periode 2014-2016. Besar kecilnya luas pengungkapan CSR yang dilaksanakan oleh perusahaan tidak mempengaruhi peningkatan nilai perusahaan. Sebagian besar perusahaan hanya 
berfokus pada faktor keuangan, sehingga perusahaan kurang berfokus pada faktor - faktor non keuangan semisal CSR.

Variabel interveningyakni CSR dinilai tidak memediasi hubungan antara Profitabilitaspada Nilai Perusahaan. Hal ini berarti bahwa profitabilitastidak dapat meningkatkan nilai perusahaan yang didukung oleh kegiatan CSRyang dilakukan oleh perusahaan. Adapun saran yang dapat diajukan dalam penelitian ini adalah penelitian ini hanya menggunakan sampel perusahaan di bidang pertambangan sehingga belum mampu merepresentasikan semua perusahaan yang ada. Peneliti selanjutnya diharapkan dapat menjadikan perusahaan di bidang lain sebagai sampel penelitian yang bertujuan agar cakupan hasil yang didapat menjadi lebih luas.

Penilaian CSR cenderung bersifat subjektif sehingga ada kemungkinan terlewatinya beberapa indikator yang sebenarnya telah diungkapkan perusahaan. Hal ini menyebabkan terjadinya perbedaan antara hasil pengamatan penulis dengan penulis lainnya. Peneliti selanjutnya dapat menilai CSR yang dilakukan oleh 2 penilai atau lebih sehingga dapat meminimalkan subjektifitas penilaian CSR. Perusahaan diharapkan tetap menerapkan CSR atau informasi tanggung jawab sosial sebagai keunggulan kompetitif perusahaan. Perusahaan harus mampu meningkatkan profitabilitas yang menunjukkan tingkat keuntungan bersih perusahaan saat menjalankan operasinya sehingga meningkatkan CSR.

Penelitian selanjutnya hendaknya mempertimbangkan beberapa variabel lain seperti kepemilikan institusional, kepemilikan kepemilikan menejerial, kepemilikan asing, kebijakan deviden dan lain sebagainya yang mungkin 
mempengaruhi nilai perusahaanuntuk meningkatkan pengetahuan mengenai nilai perusahaan di Indonesia.

\section{REFERENSI}

Adri, Fazdlilah 2014. Pengaruh Kepemilikan Manajerial, Struktur Modal, Kinerja Keuangan Terhadap Nilai Perusahaan (Property dan Real Estate). Jom Fekom. Vol. 1, No.2. Jurusan Akuntansi Fakultas Ekonomi Universitas Riau.

Agustina, Silvia. 2012. Pengaruh Profitabilitas dan Pengungkapan Corporate Social Responsibility Terhadap Nilai Perusahaan. Skripsi. Universitas Negeri Padang

Anggraini, Dina. 2013. Pengaruh Good Corporate Governance Terhadap Nilai Perusahaan Pada Perusahaan Textil, Garment yang terdaftar di Bursa Efek Indonesia (BEI) Periode 2009-2012. Jurnal Umrah. 2014

Astiari, Luh Putu. 2014. Pengaruh Pertanggung Jawaban Sosial Perusahaan Terhadap Nilai Perusahaan Dengan Profitabilitas Sebagai Variabel Moderating (Studi Empiris Pada Perusahaan Manufaktur yang Terdaftar di Bursa Efek Indonesia). E-Jurnal S1 Ak Universitas Pendidikan Ganesha Jurusan Akuntansi. Vol 2, No. 1, 2014.

Brigham, F., dan J. Houston. 2001. Manajemen Keuangan, Edisi Kedelapan. Jakarta: Erlangga.

Darwin, A. 2007. The 2nd Sustainability Enterprise Performance Conference (SEPC). ISRA. September 2007.

Dewi, Mahatma. 2013. Pengaruh Struktur Modal, Profitabilitas dan Ukuran Perusahaan pada Nilai Perusahaan. E-journal Universitas Udayana. Vol.4, No. 2, 2013.

Dinata, I Made. 2013. Pengaruh Profitabilitas dan Struktur Kepemilikan Terhadap Kebijkan Deviden dan Nilai Perusahaan. E-Jurnal Universitas Udayana.

Fodio, Musa Inuwa, Abdullahi Musa- bu Abdiss Amad dan Victor Chiedu Oba. 2013. Corporate Social Responsibility and Firm Value in Quoted Nigerian Financial Services. International Journal of Finance and Accounting, 2(7), pp: 331-340.

Gherghina, Stefan Christian, Georgeta Vintila and Diana Dobrescu. 2015. An Empirical Research on the Relationship Between Corporate Social Responsibility Ratings and U.S. Listed Companies Value. Journal of Economics Studies and Research, 10(1), pp: 1-11. 
Gumanti, T.A. 2009. Teori Sinyal dalam Manajemen Keuangan. Majalah USAHAWAN, No. 06 Th XXXVIII. Jakarta: Lembaga Management FEUI.

Harjoto, Maretno A., and Jo, Hoje. 2011. Corporate Governance and CSR Nexus. Journal of Business Ethics (JBE) special issue.

Haruman, Tendi. 2008. "Pengaruh Struktur Kepemilikan Terhadap Keputusan Keuangan dan Nilai Perusahaan". Simposium Nasional Akuntansi XI. Pontianak.

Irma, Ni Kadek. 2014. Pengaruh Kinerja Pada Nilai Perusahaan Dengan Corporate Social ResponsibilitySebagai Variabel Pemoderasi. E-Jurnal Universitas Udayana. Vol. 7, No. 3, 2014.

Jensen, M.C., and Meckling, W.H. 1976. Theory of The Firm: Managerial Behavior, Agency Costs, and Ownership Structure. Journal of Financial Economic 3, pp: 305-360.

Ju Chen, Li and Yu Chen, Shun. 2011. The Influence of Profitability on Firm Value with Capital Structure as The Mediator and Firm Size and Industry as Moderator. Investment Management and Financial Innovations. Vol. 8, Issue 3.

Kusumadilaga, Rimba. 2010. Pengaruh Corporate Social Responsibility terhadap Nilai Perusahaan dengan Profitabilitas sebagai Variabel Moderating (Studi Empiris pada Perusahaan Manufaktur yang terdaftar di Bursa Efek Indonesia). Skripsi Fakultas Ekonomi Universitas Diponegoro Semarang.

Maria, Ni Luh. 2013. Pengaruh Kinerja Keuangan Terhadap Nilai Perusahaan Dengan Pemoderasi Good Corporate Governance dan Corporate Social Responsibility. E-Journal Universitas Udayana. Vol. 3, No. 1.

McWiliams, A. dan Siegel, D. 2001. Corporate Social Responsibility: A Theory of the Firm Perspective. The Academy of Management Review, 26 (1), 117.127 .

Munawir. 2010. Analisis Laporan Keuangan. Edisi 4. Yogyakarta: Liberty.

Murwaningsari, E. 2009. Hubungan Corporate Governance, Corporate Social Responsibility dan Corporate Financial Performance dalam Satu Continuum. Jurnal Akuntansi dan Keuangan, 11(1), hal: 30-41.

Nguyen, Bich Thi, Hai Thi Thanh Tran, Oanh Huang Le, Phuoc Thi Nguyen, Thien Hiep Trinh and Viet Le. 2015. Association between Corporate Social Responsibility Disclosures and Firm Value - Empirical Evidence from Vietnam. International Journal of Accounting and Financial Reporting, 5(1), pp: 212-228. 
Nikolis, Jenri. 2013. Analisis Pengaruh Struktur Modal, Kepemilikan Manajerial, Kepemilikan Institusional dan Profitabilitas Terhadap Nilai Perusahaan (Studi pada Perusahaan Non Perbankan yang Terdaftar di BEI Tahun 2009-2010). Skripsi. Fakultas Ekonomika dan Bisnis Universitas Diponegoro, Semarang.

Nurlela dan Islanhudin. 2008. Pengaruh Corporate Social Responsibility Terhadap Nilai Perusahaan dengan Prosentasi Kepemilikan Manajemen sebagai Variabel Moderating. Simposium Nasional Akuntansi XI.

Pebriana. 2012. Pengaruh Profitabilitas, Leverage, Umur Perusahaan, Komposisi Dewan Direksi Dan Kepemilikan Instusional Pada Pengungkapan Corporate Social Responsibility (Csr) Di Bursa Efek Indonesia.

Putra, C.G.B., Rasmini, N.K., dan Astika, I. B. P. 2013. Pengaruh Corporate Social Responsibility Pada Price to Book Value Dengan Corporate Governance sebagai Variabel Moderasi. E-Jurnal Ekonomi dan Bisnis Universitas Udayana, 2(5), h:339-353.

Rani, Widiyasari Eko Putri. 2013. Pengaruh Profitabilitas Terhadap Pengungkapan Corporate Social Responsibility (Studi Empiris Pada Perusahaan Pertambangan Yang Terdaftar Di Bursa Efek Indonesia Pada Tahun 2010 - 2012. Jurnal Akuntansi Universitas Brawijaya, 2(2), h:1-26.

Rustariani, Ni Wayan. 2010. Pengaruh Corporate Governance pada Hubungan Corporate Social Responsibility dan Nilai Perusahaan. Simposium Nasional Akuntansi XIII.

Ross, S. 1977. The Determination of Financial Structure: The Incentive Signaling Approach. Bell Journal of Financial Economics, 8(1), pp: 823-40.

Sari, Rizkia Anggita. 2012. Pengaruh Karakteristik Perusahaan Terhadap Corporate Social Responsibility Disclosure pada Perusahaan Manufaktur yang Terdaftar di Bursa Efek Indonesia. Jurnal Nominal, 1(1). Universitas Negeri Yogyakarta

Sembiring. 2005. Kinerja Keuangan, Political Visibility, Ketergantungan pada Hutang, dan Pengungkapan Tanggung Jawab Sosial Perusahaan. Simposium Nasional Akuntansi VII.

Soliha, E. dan Taswan. 2002. Pengaruh Kebijakan Hutang terhadap Nilai Perusahaan serta Beberapa Faktor yang Mempengaruhinya. Jurnal Bisnis dan Ekonomi. Vol. 9. No. 2. September: $149-163$.

Su'aidah, Sitta. 2010. Pengaruh ROA Dan ROE Terhadap Nilai Perusahaan Dengan Pengungkapan Corporate Social Responsibility dan Kepemilikan Manajerial Sebagai Variabel Pemoderasi. Skripsi. Sekolah Tinggi Ilmu Ekonomi Perbanas Surabaya. 
Sugiyono, 2014. Metode Penelitian Bisnis. Bandung: Alfabeta

Susianti, Ni Luh. 2013. Pengaruh Kinerja Keuangan Terhadap Nilai Perusahaan Dengan Pemoderasi Good Corporate GovernanceDan Corporate Social Responsibility. E-Journal Universitas Udayana. Vol. 3, No. 1. Pp. 73-91.

Syarifa, Hurul. 2013. Pengaruh Return on Asset (ROA) Return on Equity (ROE) dan Kepemilikan Manejerial Terhadap Nilai Perusahaan (Studi Empiris Pada Perusahaan Manufaktur Di Bursa Efek Indonesia (BEI) Periode 2009-2011). Skripsi. Universitas Bina Nusantara.

Uadiale, Olayinka Marte and Temitope Olamide Fagbemi. 2012. Corporate Social Responsibility and Financial Perfomance in Developing Economies: The Nigerian Experience. Journal of Economics and Sustainable Development, 3(4), pp: 44-54.

Vintila, Georgeta dan Florinita Duca. 2013. A Study of the Relationship between Corporate Responsibility - Financial Performance - Firm Size. Revista Romana de Statistica Trim, 1(1), pp: 62-67.

Wahyudi, Asto. 2012. Pengaruh Profitabilitas, Likuiditas, dan Leverage Terhadap Nilai Perusahaan (Studi Pada Perusahaan Sektor Manufaktur Di Bursa Efek Indonesia Periode 2008-2011). Artikel. Program Studi Megister Manajemen Program Pasca Sarjana Universitas Muhammadiyah, Surakarta.

Wahyudi, Untung dan Hartini Prasetyaning Pawestri. 2006. Implikasi Struktur Kepemilikan Terhadap Nilai Perusahaan: Dengan Keputusan Keuangan Sebagai Variabel Intervening, Simposium Nasional Akutansi 9. Padang.

Wiagustini, Ni luh Putu. 2010. Dasar-Dasar Manajemen Keuangan. Denpasar. Udayana University Press.

Wibowo, Ramadani. 2011. Pengaruh Profitabilitas, Kepemilikan Manajerial, Kebijak Deviden, dan Leverage Terhadap Nilai Perusahaan. Jurnal Ilmiah Mahasiswa Administrasi Bisnis. Universitas Brawijaya.

Yuniasih, Ni Wayan dan Wirakusuma, Made. 2009. Pengaruh Kinerja Keuangan Terhadap Nilai Perusahaan Dengan Pengungkapan Corporate Social Responsibility Dan Good Corporate Governance Sebagai Variabel Pemoderasi. E-Journal Universitas Udayana. 